\title{
Effect of copper intake on CSF parameters in patients with mild Alzheimer's disease: a pilot phase 2 clinical trial
}

\author{
Holger Kessler · Frank-Gerald Pajonk · Daniela Bach · Thomas Schneider-Axmann • \\ Peter Falkai · Wolfgang Herrmann · Gerd Multhaup · Jens Wiltfang · \\ Stephanie Schäfer · Oliver Wirths · Thomas A. Bayer
}

Received: 6 June 2008/Accepted: 5 October 2008/Published online: 30 October 2008

(C) The Author(s) 2008. This article is published with open access at Springerlink.com

\begin{abstract}
A plethora of reports suggest that copper $(\mathrm{Cu})$ homeostasis is disturbed in Alzheimer's disease (AD). In the present report we evaluated the efficacy of oral $\mathrm{Cu}$ supplementation on CSF biomarkers for AD. In a prospective, randomized, double-blind, placebo-controlled phase 2 clinical trial (12 months long) patients with mild $\mathrm{AD}$ received either $\mathrm{Cu}$-(II)-orotate-dihydrate (verum group; $8 \mathrm{mg} \mathrm{Cu}$ daily) or placebo (placebo group). The primary outcome measures in CSF were $\mathrm{A} \beta 42$, Tau and Phospho-Tau. The clinical trial demonstrates that longterm oral intake of $8 \mathrm{mg} \mathrm{Cu}$ can be excluded as a risk factor for $\mathrm{AD}$ based on CSF biomarker analysis. $\mathrm{Cu}$ intake had no effect on the progression of Tau and Phospho-Tau levels in CSF. While A $\beta 42$ levels declined by $30 \%$ in the placebo group $(P=0.001)$, they decreased
\end{abstract}

H. Kessler, F.-G. Pajonk and D. Bach contributed equally to this work.

H. Kessler · D. Bach

Department of Psychiatry and Psychotherapy,

Saarland University Hospital, Homburg/Saar, Germany

F.-G. Pajonk

Center for Psychiatric and Psychotherapeutic Care

and Rehabilitation, Dr K. Fontheim's Hospital

for Mental Health, Liebenburg, Germany

T. Schneider-Axmann · P. Falkai · S. Schäfer · O. Wirths ·

T. A. Bayer $(\square)$

Division of Molecular Psychiatry, Department of Psychiatry

and Psychotherapy, University Medicine Goettingen,

von-Siebold-Strasse 5, 37075 Goettingen, Germany

e-mail: tbayer@gwdg.de

W. Herrmann

Department for Clinical Chemistry, Central Laboratory,

Saarland University Hospital, Homburg/Saar, Germany only by $10 \%(P=0.04)$ in the verum group. Since decreased CSF $\mathrm{A} \beta 42$ is a diagnostic marker for $\mathrm{AD}$, this observation may indicate that $\mathrm{Cu}$ treatment had a positive effect on a relevant $\mathrm{AD}$ biomarker. Using mini-mental state examination (MMSE) and Alzheimer disease assessment scale-cognitive subscale (ADAS-cog) we have previously demonstrated that there are no $\mathrm{Cu}$ treatment effects on cognitive performance, however. Finally, CSF A $\beta 42$ levels declined significantly in both groups within 12 months supporting the notion that CSF A $\beta 42$ may be valid not only for diagnostic but also for prognostic purposes in $\mathrm{AD}$.

Keywords $\mathrm{Cu} \cdot$ Alzheimer $\cdot$ Clinical trial $\cdot$ Tau . CSF, plasma $\cdot$ Abeta

G. Multhaup

Institute for Chemistry and Biochemistry,

Free University, Berlin, Germany

J. Wiltfang

Department of Psychiatry and Psychotherapy,

Rheinische Kliniken Essen, University of Duisburg-Essen,

Essen, Germany

Present Address:

S. Schäfer

Neuroscience Research, GPRD, Abbott,

Ludwigshafen, Germany 


\section{Introduction}

One major pathological hallmark of Alzheimer's disease (AD) is the deposition of $\beta$-amyloid (A $\beta$ ) plaques in the brain. A $\beta$ peptides result from enzymatic processing of the $\beta$-amyloid precursor protein (APP) by $\beta$ - and $\gamma$-secretases. Since cerebrospinal fluid (CSF) is in direct contact with the central nervous system (CNS), measurement of the CSF concentration of $\mathrm{A} \beta$ peptides has shown to represent one biomarker, which-especially in combination with increased Tau protein concentration in CSF-can improve the safety of clinical AD diagnosis. The normal level of A $\beta 1-42$ is regularly found decreased to about $50 \%$ in patients with AD (Lewczuk et al. 2004; Wiltfang et al. 2001, 2002). Among other possible factors which require a confirmation the most accepted explanation is the accumulation of $\mathrm{A} \beta$ in plaques leading to decreased $\mathrm{A} \beta 42$ levels in the CSF of AD patients.

Potentially toxic $\mathrm{A} \beta$ peptides are generated from the copper-binding APP by two independent proteolytic events (Bayer et al. 2001; Glenner and Wong 1984; Hesse et al. 1994; Kang et al. 1987). APP is actively involved in balancing $\mathrm{Cu}$ concentrations in cells. In APP-knock-out mice, $\mathrm{Cu}$ levels were found increased in cerebral cortex and liver (White et al. 1999), whereas overexpression of APP was reported to result in significantly reduced $\mathrm{Cu}$ levels in brain tissue of different APP transgenic mouse strains (Bayer et al. 2003; Phinney et al. 2003) and in mice overexpressing the C-terminal fragment of APP (and enhanced $\mathrm{A} \beta$ secretion) (Maynard et al. 2002).

The N-terminal $\mathrm{Cu}$ binding domain (CuBD-I) of APP shows structural homology to the $\mathrm{Cu}$ binding domain of $\mathrm{Cu}$ chaperons (Barnham et al. 2003) binding Cu with nanomolar affinity (Hesse et al. 1994). A secondary CuBD-II appears in $\mathrm{A} \beta$ after its release from APP (Atwood et al. 2000), and $\mathrm{Cu}$ application was reported to increase $\mathrm{A} \beta$ aggregation in vitro [reviewed in (Bush 2003)]. APP reduces $\mathrm{Cu}(\mathrm{II})$ to $\mathrm{Cu}(\mathrm{I})$, leading to oxidative modification of APP (Multhaup et al. 1996), which is facilitated through the protein surface localization of the binding site thus resembling so called cytoplasmic $\mathrm{Cu}$ chaperones (Barnham et al. 2003).

In cell culture systems, $\mathrm{Cu}$ supplementation was found to stimulate the non-amyloidogenic APP pathway thereby suppressing the formation of $\beta$ amyloid (Borchardt et al. 1999). More recently, APP was shown in yeast cells to have a $\mathrm{Cu}$ efflux activity thereby explaining why APP overexpressing mice have a reduced $\mathrm{Cu}$ level in their brains (Bayer et al. 2003; Phinney et al. 2003; Treiber et al. 2004). Earlier studies in animals have reported that elevated $\mathrm{Cu}$ is a risk factor for developing the $\mathrm{AD}$ related pathology. Cherny et al. (2001) showed that clioquinol, a $\mathrm{Cu}$ and $\mathrm{Zn}$ chelating agent, can remove $\beta$-amyloid plaque pathology. However, it was unclear how this effect worked, since the authors reported an increase of soluble $\mathrm{Cu}$ and $\mathrm{Zn}$ levels in the brain of treated mice. This apparently contradictory finding could be explained by the finding that clioquinol mediates $\mathrm{Cu}$ uptake by transporting $\mathrm{Cu}$ across cell membranes counteracting $\mathrm{Cu}$ efflux activities of APP (Treiber et al. 2004).

The observation that dietary $\mathrm{Cu}$ supplementation in a transgenic mouse model for $\mathrm{AD}$ does not only increase bioavailable brain $\mathrm{Cu}$ levels and restores superoxide dismutase-1 (SOD-1) activity but also lowers $\mathrm{A} \beta$ levels in the brain and prevents premature death, supports the notion that a disturbed $\mathrm{Cu}$ homeostasis may be associated with the pathological process in AD (Bayer et al. 2003). Furthermore, increasing $\mathrm{Cu}$ levels by genetic means reduced $\mathrm{A} \beta$ plaque load and rescued the premature death of APP transgenic mice (Phinney et al. 2003).

Normally, $\mathrm{Cu}$ contained in the food is taken up in the stomach and then absorbed in the small intestine. About $30-50 \%$ of the $\mathrm{Cu}$ is absorbed. $\mathrm{Cu}$ is distributed from the liver throughout the body and transported in the bloodstream bound to ceruloplasmin. The liver is the most important organ for $\mathrm{Cu}$ distribution and storage. $\mathrm{Cu}$ is excreted via the biliary system. Usually, $2 \mathrm{mg}$ of $\mathrm{Cu}$ per day are taken with food. Ingestion of as much as $10 \mathrm{mg}$ of $\mathrm{Cu}$ per day is considered to be safe. The clinical reference value for physiological $\mathrm{Cu}$ plasma concentrations is 65 $165 \mu \mathrm{g} / \mathrm{dl}$ [reviewed in (Kessler et al. 2005)]. In an earlier report we could show a negative correlation between plasma $\mathrm{Cu}$ and ADAS-cog score in AD patients, i.e. cognitive performance in patients with $\mathrm{Cu}$ levels within the lower third of the physiological range was worse than in patients with higher $\mathrm{Cu}$ plasma levels (Pajonk et al. 2005). In addition, $\mathrm{AD}$ patients fulfilling the criteria of CSF diagnosis for $\mathrm{AD}$ (defined as at least two of three markers [A $\beta 42$, Tau, Phospho-Tau] being out of the reference range) had significantly lower blood $\mathrm{Cu}$ levels than $\mathrm{AD}$ patients who fulfilled none or only one of these CSF criteria (Kessler et al. 2006).

Taken together, this brought us to hypothesize that restoring brain $\mathrm{Cu}$ homeostasis might have a beneficial influence on the progression of $\mathrm{AD}$. We speculated that oral $\mathrm{Cu}$ supplementation may stabilize CSF biomarker parameters in $\mathrm{AD}$ patients. Thus, we monitored the progression of the disease in $\mathrm{AD}$ patients by recording the changes in CSF and plasma within 12 months in a prospective, randomized, double-blind pilot phase 2 clinical trial.

\section{Material and methods}

Study population

Criteria for participation in the study included written informed consent as well as caregiver consent, a diagnosis 
of probable AD by means of NINCDS-ADRDA criteria (McKhann et al. 1984), a MMSE score of 20-25. All patients received 5-10 mg donepezil daily. Patients with severe and unstable somatic diseases and patients with present or known history of alcohol, drug or medication abuse were excluded. Patients taking drugs for coexistent diseases were included except those taking psychotropic drugs, "nootropics" or health food supplements. The trial has been approved by the appropriate ethics committee and has therefore been performed in accordance with the ethical standards laid down in the 1964 Declaration of Helsinki.

\section{Study design}

The study had a monocentric, prospective, double-blind, placebo-controlled, parallel-group randomized design. In total 68 patients were recruited. Screening procedure consisted of a medical history, physical examination, psychometric tests, blood tests, MRT scan and diagnostic lumbar puncture. After 1 year a second lumbar puncture was obtained to monitor possible CSF changes. Patients were randomly allocated either to placebo or to verum $(\mathrm{Cu}$ orotate). The oral dosage of $\mathrm{Cu}$ orotate was $51.62 \mathrm{mg}$ (corresponding to $8 \mathrm{mg} \mathrm{Cu}$ ) once daily. To maintain blinding, capsules containing $\mathrm{Cu}$ orotate and placebo had identical shape and colour. The duration of the study was 12 months. The study was registered at http://www.clinicaltrials.gov with the identification number NCT00608946.

\section{Outcome measures}

The primary efficacy variables were the changes from the baseline score in the CSF A $\beta 42$, Tau and Phospho-Tau levels. Efficacy evaluations were performed at baseline and after 12 months.

\section{CSF sampling}

CSF was drawn from patients by lumbar puncture in the afternoon, sampled in polypropylene vials and centrifuged $\left(1,000 \mathrm{~g}, 10 \mathrm{~min}, 4^{\circ} \mathrm{C}\right)$. Aliquots of $250 \mu \mathrm{l}$ were stored at $-80^{\circ} \mathrm{C}$. Freezing of samples was conducted by directly cooling $250 \mu \mathrm{l}$ of $\mathrm{CSF}$ in polypropylene tubes down to $-80^{\circ} \mathrm{C}$ without an intermediate temperature stage. The samples did not undergo additional freeze and thaw cycles.

\section{A $\beta 42$, Tau and Phospho-Tau quantification by ELISA}

CSF amyloid beta $1-42$ (A $\beta 42)$, CSF total Tau, and CSF

Tau phosphorylated at threonine-181 (Phospho-Tau) were quantified using ELISA as recommended by the manufacturer (Innogenetics, Gent, Belgium; carried out at the Medizinisches Labor Bremen, Germany). CSF samples for ELISA were analysed at different time points.

Urea gel electrophoresis for $\mathrm{A} \beta 1-37,1-38,1-39$, 1-40 and 1-42 quantification by Western blotting

CSF proteins were separated on $10 \%$ Bicine/Tris gels containing $8 \mathrm{M}$ urea (22), and $\mathrm{A} \beta$ peptide species were revealed by western blotting using antibody $1 \mathrm{E} 8$. Synthetic $\mathrm{A} \beta$ peptides of different size were run in parallel in the same gel system and under the same conditions for the identification and quantification of $\mathrm{A} \beta$ peptides by densitometry. Immunoreactive band intensities were quantified with the Quantity One v4.1 software (Bio-Rad). All samples were run as duplicates and each gel carried a five-step dilution series of a synthetic $\mathrm{A} \beta$ peptide mix. Bands were quantified relative to this dilution series. The inter- and intra-assay coefficients were below 10\%. Mean values were used for subsequent calculations. The CSF samples were analysed altogether at one time point.

\section{$\mathrm{Cu}, \mathrm{Zn}$ and ceruloplasmin in blood}

Blood was collected to determine the level of $\mathrm{Cu}$ and, $\mathrm{Zn}$ by using atomic absorption spectroscopy (AAS) and to analyze ceruloplasmin by the nephelometric method (see below). Blood samples were collected into metal-free tubes that contained lithium heparin as an anti-coagulant. Concentrations of $\mathrm{Cu}$ were measured in lithium-heparin plasma samples, utilizing flame AAS (PerkinElmer, AAnalyst 800). Samples were diluted with deionised water, and the analysis was performed using standards prepared in glycerol to approximate the viscosity characteristics of the diluted samples. Standard atomic absorption conditions were utilized for $\mathrm{Cu}$ (air acetylene, wave length $324.8 \mathrm{~nm}$ ). The between-day coefficient of variation $(\mathrm{CV} \%)$ for $\mathrm{Cu}$ assay was $4.24 \%$ (at $88 \mu \mathrm{g} / \mathrm{dl}$ ), and the between-day coefficient of variation (CV\%) for $\mathrm{Zn}$ assay was $7.21 \%$ (at $317 \mu \mathrm{g} / \mathrm{dl}$ ). $\mathrm{Cu}, \mathrm{Zn}$ and ceruloplasmin samples were analysed immediately after collection.

Ceruloplasmin has been determined by immunochemical reaction utilizing the nephelometric method (Behring Nephelometer BN II). Reagents and quality control sera were provided by Dade Behring Company (Germany). The results were evaluated by means of logit-log function. Samples containing particles were centrifuged prior to testing. Plasma specimens were automatically diluted 1:20 with $\mathrm{N}$ Diluent. The analytical imprecision has been determined as follows: intra-assay $\mathrm{CV} 1.4 \%$, interassay $\mathrm{CV} 1.8 \%$. The expected reference range utilising this method was between 0.2 and $0.6 \mathrm{~g} / 1 \quad\left(\mathrm{P}_{2.5}-\mathrm{P}_{97.5}\right.$ percentile). 


\section{$\mathrm{Cu}$ levels in $\mathrm{CSF}$}

Inductively coupled plasma mass spectrometry (ICP-MS): for analysis of metal concentrations $(\mathrm{Cu}$ and $\mathrm{Zn})$ in $\mathrm{CSF}$, samples were prepared by $\mathrm{HNO}_{3}$ closed-vessel microwave digestion and diluted in Milli-Q water to a final concentration of $6.5 \% \mathrm{HNO}_{3}$ for analysis by ICP-MS. ICP-MS was performed by using a HP4500 Series 300 ShieldTorch system instrument (Agilent, Waldbronn, Germany) in peak-hopping mode with spacing at 0.05 atomic mass units, three points per peak, three scans per replicate, and an integration time of $300 \mathrm{~ms}$ per point. The rate of plasma flow was $15 \mathrm{l} / \mathrm{min}$ with an auxiliary flow of $1.0 \mathrm{l} / \mathrm{min}$. The replicative form power was $1.2 \mathrm{~kW}$. The sample was introduced by using a crossflow nebulizer at a flow rate of $1.02 \mathrm{l} / \mathrm{min}$. The CSF samples were analysed at one time point.
Safety measures

Standard adverse event reporting was conducted. Before baseline, the $\mathrm{Cu}$ content in drinking water at the patients' home was analyzed under standard conditions; concentration of $\mathrm{Cu}$ in drinking water must not exceed $2 \mathrm{mg} / \mathrm{l}$. For safety reasons, blood analyses (including especially plasma $\mathrm{Cu}$ levels and liver enzymes) were performed at week 1, 2, 3 and 4 after baseline and at month 3, 6, 9 and 12 .

Data analysis

For statistical analyses SPSS 15 for Windows was used. Significance level was $\alpha=0.05$. All tests were two-tailed. Demographic variables and data on the course of the disease at screening time $\left(t_{1}\right)$ were compared between the verum and the placebo group with one-way analysis of variance

Table 1 Demographic and clinical data of patients at screening time $\left(\mathrm{t}_{1}\right)$ that have completed the clinical trial

\begin{tabular}{|c|c|c|c|c|c|c|c|}
\hline & & Placebo & & & $\chi^{2}$ & $d f$ & $P$ \\
\hline Gender (no. male; no. female) & & m.:12; f.: 21 & & 17; f: 18 & 1.04 & 1 & 0.31 \\
\hline \multirow[t]{2}{*}{ APOE: number of E4 alleles $(0,1,2)$} & & $0: 9 ; 1: 13 ; 2: 2$ & & $1: 16 ; 2: 2$ & 0.54 & 2 & 0.76 \\
\hline & $n$ & Mean \pm SEM & $n$ & Mean \pm SEM & $F$ & $d f$ & $P$ \\
\hline Age (years) & 33 & $69.48 \pm 1.39$ & 35 & $70.37 \pm 1.12$ & 0.25 & 1,66 & 0.62 \\
\hline Disease Duration (months) & 33 & $24.73 \pm 2.69$ & 34 & $33.26 \pm 4.97$ & 2.25 & 1,65 & 0.14 \\
\hline Age at onset (years) & 33 & $67.48 \pm 1.34$ & 34 & $67.50 \pm 1.09$ & 0.00 & 1,65 & 0.99 \\
\hline Education (years) & 32 & $10.31 \pm 0.35$ & 34 & $11.41 \pm 0.47$ & 3.53 & 1,64 & 0.065 \\
\hline CDT (score) & 33 & $2.82 \pm 0.23$ & 34 & $2.88 \pm 0.21$ & 0.04 & 1,65 & 0.84 \\
\hline MMSE (total score screening) & 33 & $23.52 \pm 0.52$ & 35 & $24.17 \pm 0.61$ & 0.66 & 1,66 & 0.42 \\
\hline
\end{tabular}

The placebo and verum group did not differ significantly in any of the variables

$\mathrm{m}$, Male; f, female; $\mathrm{n}$, number of cases; $\mathrm{m}$, mean; SEM, standard error of the mean; $\chi^{2}, \chi^{2}$ statistics; df, degrees of freedom; F, $F$ statistics; CDT, clock drawing test; MMSE, mini mental state examination

Table 2 Demographic and clinical data of patients with CSF collections at screening time $\left(t_{1}\right)$ at the beginning and at the end of the study

\begin{tabular}{|c|c|c|c|c|c|c|c|}
\hline & & Placebo & & & $\chi^{2}$ & $d f$ & $P$ \\
\hline Gender (no. male; no. female) & & m.:4; f.: 13 & & ; f: 7 & 5.04 & 1 & 0.025 \\
\hline \multirow[t]{2}{*}{ APOE: number of E4 alleles $(0,1,2)$} & & $0: 6 ; 1: 8 ; 2: 1$ & & $: 12 ; 2: 2$ & 3.10 & 2 & 0.21 \\
\hline & $n$ & Mean \pm SEM & $n$ & Mean \pm SEM & $F$ & $d f$ & $P$ \\
\hline Age (years) & 17 & $67.76 \pm 1.72$ & 18 & $68.94 \pm 1.67$ & 0.24 & 1,33 & 0.63 \\
\hline Disease Duration (months) & 17 & $23.12 \pm 3.79$ & 18 & $31.50 \pm 8.52$ & 0.78 & 1,33 & 0.38 \\
\hline Age at onset (years) & 17 & $65.94 \pm 1.72$ & 18 & $66.44 \pm 1.50$ & 0.05 & 1,33 & 0.83 \\
\hline Education (years) & 17 & $10.59 \pm 0.54$ & 18 & $12.06 \pm 0.67$ & 2.86 & 1,33 & 0.10 \\
\hline CDT (score) & 17 & $2.76 \pm 0.36$ & 18 & $2.94 \pm 0.27$ & 0.16 & 1,33 & 0.69 \\
\hline MMSE (total score screening) & 17 & $23.71 \pm 0.83$ & 18 & $23.67 \pm 0.95$ & 0.00 & 1,33 & 0.98 \\
\hline
\end{tabular}

m, Male; f, female; $n$, number of cases; $m$, mean; SEM, standard error of the mean; $\chi^{2}, \chi^{2}$ statistics; df, degrees of freedom; F, $F$ statistics; CDT, clock drawing test; MMSE, mini mental state examination 
(ANOVA). $\chi^{2}$ test on independence was used to analyze, if the gender distribution was different between the two groups and if the number of APOE E4 alleles differed between the groups (Tables 1, 2). Primary dependent variables were ELISA A $\beta$ levels of $\mathrm{A} \beta 42$, Tau and PhosphoTau. They were expressed as absolute numbers at the starting point $\left(t_{1}\right)$ and 12 months later at the end of the study $\left(t_{12}\right)$. Secondary dependent variables were: Western blot $\mathrm{A} \beta$ levels, expressed as \% of total A $\beta$ : $1-42,1-40,1-39,1-38$, $1-37 \%$, or as $\mathrm{A} \beta$ ratios $1-42 / 1-40,1-42 / 1-38,1-38 / 1-40$, such as cholesterol, plasma $\mathrm{Zn}$, ceruloplasmin, plasma $\mathrm{Cu}$ and $\mathrm{CSF} \mathrm{Cu}$ values, expressed as absolute numbers at $t_{1}$ and $t_{12}$. Independent between-subject factor was group (placebo, verum), within-subject factor was time of measurement. Kolmogorov-Smirnov tests were used to test, if there were significant deviations of the dependent variables from the normality assumption. At $t_{1}$ (Table 3) and $t_{12}$ (Table 4) one-way ANOVA with fixed factor group was performed for the dependent variables and found to be normal distributed. For the variables, where the normality

Table 3 Descriptive Statistics at screening time (t1), ANOVA/Mann-Whitney U test

\begin{tabular}{|c|c|c|c|c|c|c|c|c|}
\hline & \multicolumn{2}{|c|}{ Placebo } & \multicolumn{2}{|c|}{ Verum } & \multirow[t]{2}{*}{$\%$ Diff. verum versus placebo } & \multicolumn{3}{|c|}{ Factor group } \\
\hline & $n$ & Mean \pm SEM & $n$ & Mean \pm SEM & & $d f$ & $F$ & $P$ \\
\hline WB: $\mathrm{A} \beta 1-42 \%$ & 11 & $4.6 \pm 0.49$ & 11 & $4.0 \pm 0.39$ & -13.8 & 1,20 & 1.0 & 0.3 \\
\hline WB: $\mathrm{A} \beta 1-40 \%$ & 11 & $66.0 \pm 1.37$ & 11 & $67.5 \pm 0.80$ & 2.1 & 1,20 & 0.8 & 0.4 \\
\hline WB: A $\beta 1-39 \%$ & 11 & $9.4 \pm 0.60$ & 11 & $9.4 \pm 0.26$ & 0.1 & 1,20 & 0.0 & 1.0 \\
\hline WB: $\mathrm{A} \beta 1-38 \%$ & 11 & $13.1 \pm 0.65$ & 11 & $12.5 \pm 0.44$ & -4.4 & 1,20 & 0.6 & 0.5 \\
\hline WB: $\mathrm{A} \beta 1-37 \%$ & 11 & $6.8 \pm 0.60$ & 11 & $6.6 \pm 0.32$ & -2.8 & 1,20 & 0.1 & 0.8 \\
\hline WB: $\mathrm{A} \beta 42 / 40$ & 11 & $0.069 \pm 0.01$ & 11 & $0.059 \pm 0.01$ & -15.0 & 1,20 & 1.3 & 0.3 \\
\hline WB: $\mathrm{A} \beta 42 / 38$ & 11 & $0.375 \pm 0.05$ & 11 & $0.328 \pm 0.03$ & -12.4 & 1,20 & 0.5 & 0.5 \\
\hline WB: $\mathrm{A} \beta 38 / 40$ & 11 & $0.200 \pm 0.01$ & 11 & $0.186 \pm 0.01$ & -7.1 & 1,20 & 0.9 & 0.4 \\
\hline Cholesterol plasma (mg/dl) & 20 & $211.0 \pm 8.98$ & 17 & $211.1 \pm 9.52$ & 0.1 & 1,35 & 0.0 & 1.0 \\
\hline $\mathrm{Zn}$ plasma $(\mu \mathrm{g} / \mathrm{ml})$ & 24 & $67.3 \pm 1.61$ & 26 & $65.9 \pm 1.47$ & -2.0 & 1,48 & 0.4 & 0.5 \\
\hline Ceruloplasmin plasma (mg/dl) & 25 & $27.8 \pm 1.07$ & 29 & $27.0 \pm 0.98$ & -2.8 & 1,52 & 0.3 & 0.6 \\
\hline $\mathrm{Cu}$ plasma $(\mu \mathrm{g} / \mathrm{dl})$ & 25 & $109.0 \pm 4.68$ & 27 & $98.5 \pm 3.41$ & -9.6 & 1,50 & 3.3 & 0.1 \\
\hline
\end{tabular}

ANOVA and Mann-Whitney $U$ test were used where appropriate and show no significant difference between the verum and placebo group n, Sample size; m, mean; SEM, standard error of the mean; \% Diff., difference verum versus placebo group in per cent terms; df, degrees of freedom; F, $F$ statistics; P, error probability for falsely rejecting the null hypothesis, that there are no mean differences between the two treatment groups; WB, Western blot: \% of total $\mathrm{A} \beta$

Table 4 Descriptive statistics at the end $\left(t_{12}\right)$, ANOVA/Mann-Whitney $U$ test

\begin{tabular}{|c|c|c|c|c|c|c|c|c|}
\hline & \multicolumn{2}{|c|}{ Placebo } & \multicolumn{2}{|c|}{ Verum } & \multirow[t]{2}{*}{$\%$ Diff. verum versus placebo } & \multicolumn{3}{|c|}{ Factor group } \\
\hline & $n$ & Mean \pm SEM & $n$ & Mean \pm SEM & & $d f$ & $F$ & $P$ \\
\hline WB: $\mathrm{A} \beta 1-42 \%$ & 11 & $4.38 \pm 0.46$ & 11 & $3.8 \pm 0.36$ & -14.3 & 1,20 & 1.2 & 0.3 \\
\hline WB: $\mathrm{A} \beta 1-40 \%$ & 11 & $65.9 \pm 1.25$ & 11 & $68.1 \pm 1.02$ & 3.2 & 1,20 & 1.7 & 0.2 \\
\hline WB: $\mathrm{A} \beta 1-39 \%$ & 11 & $9.5 \pm 0.56$ & 11 & $9.1 \pm 0.36$ & -4.3 & 1,20 & 0.4 & 0.5 \\
\hline WB: $\mathrm{A} \beta 1-38 \%$ & 11 & $12.9 \pm 0.58$ & 11 & $12.5 \pm 0.37$ & -3.6 & 1,20 & 0.5 & 0.5 \\
\hline WB: $\mathrm{A} \beta 1-37 \%$ & 11 & $7.2 \pm 0.65$ & 11 & $6.6 \pm 0.37$ & -8.5 & 1,20 & 0.7 & 0.4 \\
\hline WB: $\mathrm{A} \beta 42 / 40$ & 11 & $0.066 \pm 0.01$ & 11 & $0.056 \pm 0.01$ & -15.7 & 1,20 & 1.4 & 0.3 \\
\hline WB: $\mathrm{A} \beta 42 / 38$ & 11 & $0.359 \pm 0.05$ & 11 & $0.301 \pm 0.03$ & -16.1 & 1,20 & 0.9 & 0.4 \\
\hline WB: $\mathrm{A} \beta 38 / 40$ & 11 & $0.198 \pm 0.04$ & 11 & $0.184 \pm 0.03$ & -7.0 & 1,20 & 1.0 & 0.3 \\
\hline Cholesterol plasma (mg/dl) & 20 & $207.8 \pm 7.46$ & 17 & $211.3 \pm 8.38$ & 1.7 & 1,35 & 0.1 & 0.8 \\
\hline Zn plasma $(\mu \mathrm{g} / \mathrm{ml})$ & 24 & $67.2 \pm 2.22$ & 26 & $70.1 \pm 2.19$ & 4.4 & 1,48 & 0.9 & 0.5 \\
\hline Ceruloplasmin plasma (mg/dl) & 25 & $29.2 \pm 0.97$ & 29 & $27.8 \pm 0.89$ & -4.6 & 1,52 & 1.0 & 0.3 \\
\hline $\mathrm{Cu}$ plasma $(\mu \mathrm{g} / \mathrm{dl})$ & 25 & $100.8 \pm 4.32$ & 27 & $100.7 \pm 2.94$ & -0.1 & 1,65 & 0.0 & 1.0 \\
\hline
\end{tabular}

ANOVA and Mann-Whitney $U$ test were used where appropriate and show no significant difference between the verum and placebo group $\mathrm{n}$, Sample size; m, mean; SEM, standard error of the mean; \% Diff., difference verum versus placebo group in per cent terms; df, degrees of freedom; F, $F$ statistics; P, error probability for falsely rejecting the null hypothesis, that there are no mean differences between the two treatment groups; WB, Western blot: \% of total $\mathrm{A} \beta$ 
assumption was rejected, non-parametric Mann-Whitney $U$ test with fixed factor group was computed. These analyses were based on the patients that completed the examinations. For Western blot and ELISA variables and CSF $\mathrm{Cu}$ it was tested if the change over time $\left(t_{12}-t_{1}\right)$ was gender related [ANOVA (gender $\times$ group) or Mann-Whitney $U$ test: males versus females separately for placebo and verum patients, respectively]. As main analysis the general linear model procedure (GLM) was used to perform a multivariate analysis of variance (MANOVA) with a repeated measure design using the within-subject factor time of measurement $\left(t_{12}\right.$ vs. $\left.t_{1}\right)$ and the between-subject factor group if the dependent variables were tested to be normal distributed. If the normality assumption was rejected, the non-parametric Wilcoxon test with the within-subject factor time ( $t_{12}$ vs. $t_{1}$ ) was done separately for the placebo and the verum group. The change over time $\left(t_{12}-t_{1}\right)$ of CSF copper values were correlated with cholesterol and $\mathrm{A} \beta 42$ differences $\left(t_{12}-t_{1}\right)$ using Spearman correlation coefficients.

\section{Power calculation}

The power calculation was based on the success criterion of the medication having an effect on the primary efficacy variables for CSF ELISA A $\beta 42$ levels applying a 5\% significance level for each analysis. Assuming a large effect size of $\left[\left(m_{\text {verum }}-m_{\text {placebo }}\right) / \sigma\right]=1$ (notations: $m_{\text {verum }}$ mean change over time $\left(t_{12}-t_{1}\right)$ in the verum group, $m_{\text {placebo }}$ mean change over time $\left(t_{12}-t_{1}\right)$ in the placebo group, $\sigma$ pooled standard deviation) and a sample size of 35 patients (CSF A $\beta 42$ : 18 in the verum group, 17 in the placebo group), the study had a power of $83 \%$ to detect significant differences between the groups.

\section{Results}

Subject recruitment and demographics

At $t_{1}$, between the placebo and the verum group there were no significant mean differences for age, disease duration, age at onset of the disease, clock drawing test and mini mental state examination at screening time. There was a trend for a longer duration of education in the verum group $(F=3.50 ; d f=1,65 ; P=0.066)$. The gender distribution was not significantly different between the verum and the placebo group. The number of APOE E4 allele carriers was not significantly different between the two groups (Table 1). Table 2 shows the demographic data of those patients with CSF samples at the beginning and the end of the study. There were also no significant mean differences for age, disease duration, age at onset of the disease, clock drawing test and mini mental state examination at screening time. However, the gender distribution was significantly different with the number of male patients was significantly higher in the verum group.

\section{Proof of concept}

Kolmogorov-Smirnov test showed that in the placebo group and in the verum group as well, there were significant deviations from the normal distribution for ELISA $\mathrm{A} \beta 42$, Tau and CSF $\mathrm{Cu}$ values. Consequently, for these variables, non-parametric tests were used. For all other dependent variables, the normality assumption could be maintained, and thus, for further analysis, parametric tests were performed. The change over time of all Western blot and ELISA variables and of CSF $\mathrm{Cu}$ was not significantly different between male versus female patients.

For most data there were no significant mean differences between the placebo and the verum group at $t_{1}$ (Table 3 ) and at $t_{12}$ (Table 4). There were significant effects of within-subject factor time for $\mathrm{A} \beta$ concentration detected by Western blot $1-42 \%$ ( $t_{12}$ vs. $t_{1}-5.9 \% ; F=5.7 ; d f=1$, $20 ; P=0.03$ ), A $\beta$ ratio $1-42 / 1-40 \%$ ( $t_{12}$ vs. $t_{1}-6.0 \%$; $F=5.1 ; d f=1,20 ; P=0.04)$, and ceruloplasmin $\%\left(t_{12}\right.$ vs. $\left.t_{1}+3.9 \% ; F=6.5 ; d f=1,52 ; P=0.01\right)$, however, these changes over time were not group related, i.e., there was no treatment effect using MANOVA with repeated measures design. Furthermore, there was a significant interaction of time and group for $\mathrm{Cu}$ in plasma ( $t_{12}$ vs. $t_{1}$ : placebo $-7.5 \%$; verum $+2.3 \% ; F=5.2 ; d f=1,50$; $P=0.03)$. For $\mathrm{Cu}$ in CSF there was a significant increase in the placebo group ( $t_{12}$ vs. $t_{1}:+211.6 \% ; Z=-2.6$; $P=0.01)$, whereas there was only a trend for an increase over time in the verum group $\left(t_{12}\right.$ vs. $t_{1}:+52.9 \% ; Z=-1.9$; $P=0.06)$.

There were no significant correlations for the change over time $\left(t_{12}-t_{1}\right)$ between cholesterol and $\mathrm{Cu}$ values in plasma (placebo: $\rho=0.02 ; d f=17 ; P=0.94$; verum: $\rho=0.21 ; d f=15 ; P=0.42$ ) as well as in CSF (placebo: $\rho=0.33 ; d f=12 ; P=0.25$, verum: $\rho=-0.15 ; d f=10$; $P=0.64)$.

In contrast to the other values CSF-A $\beta 42$, CSF-Tau and $\mathrm{CSF}-\mathrm{Cu}$ levels did not show a normal distribution, therefore non-parametric Wilcoxon tests were used to compare time point $t_{1}$ at the beginning and $t_{12}$ at the end of study. CSF A $\beta 42$ was significantly decreased in both $\mathrm{Cu}$-treated $(P=0.04)$ and placebo $(P=0.001)$ groups after 12 months. Of interest $\mathrm{A} \beta 42$ levels deceased by $30 \%$ in the placebo group, whereas only $10 \%$ in the $\mathrm{Cu}$ treated group, which may be regarded as a mild treatment effect. No significant effects were seen in Tau, P-Tau and $\mathrm{Cu}$ levels. CSF $\mathrm{Cu}$ levels in the placebo group increased significantly $(P=0.01)$ due to lower levels at the beginning, however, there was no significant group effect. P-Tau levels were 
Fig. 1 CSF parameters before and at the end of the clinical study. A $\beta 42$, Tau and $\mathrm{Cu}$ CSF levels did not elicit normal distribution, therefore nonparametric Wilcoxon tests were used to compare time point $t_{1}$ at the beginning and $t_{12}$ at the end of study. a CSF A $\beta 42$ was significantly decreased in both Cu-treated $(P=0.04)$ and placebo $(P=0.001)$ groups after 12 months. Of interest A $\beta 42$ levels deceased by $30 \%$ in the placebo group, whereas only by $10 \%$ in the $\mathrm{Cu}$ treated group. b No significant effect was seen in Tau levels. c CSF $\mathrm{Cu}$ levels in the placebo group increased significantly $(P=0.01)$ due to lower levels at the beginning, however, there was no significant $\mathrm{Cu}$-treatment effect. d P-Tau levels showed no significant differences. All values represent mean and SEM. Number of samples for $\mathrm{A} \beta 42$, Tau and P-Tau was 17 in placebo and 18 in the verum group. Number of samples for $\mathrm{Cu}$ analysis in CSF was 13 in the placebo and 14 in the verum group
CSF A 42

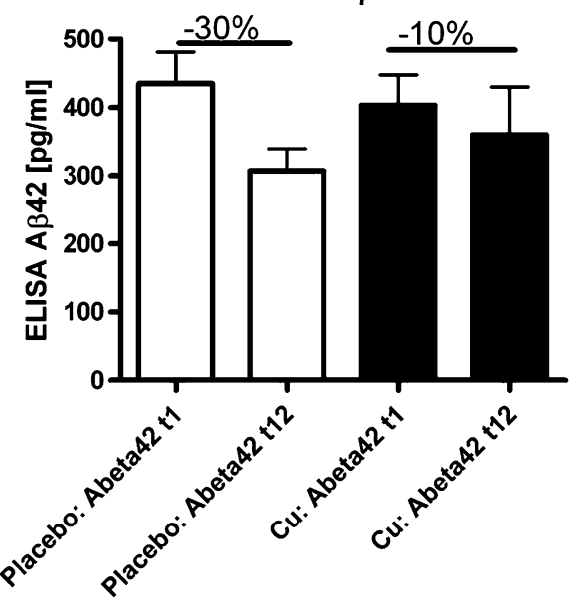

CSF Cu

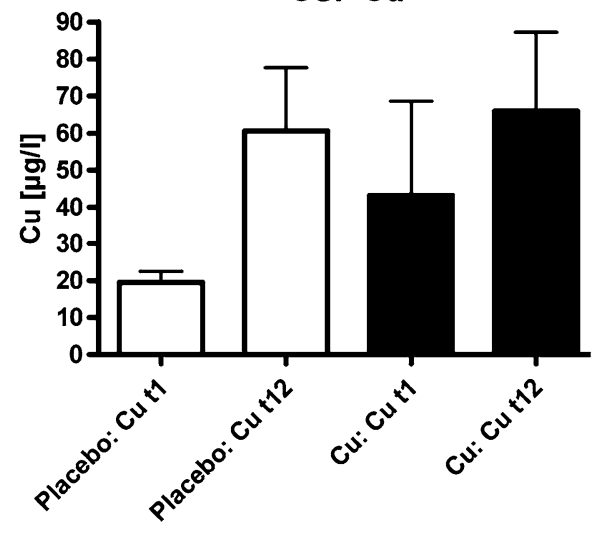

CSF Tau

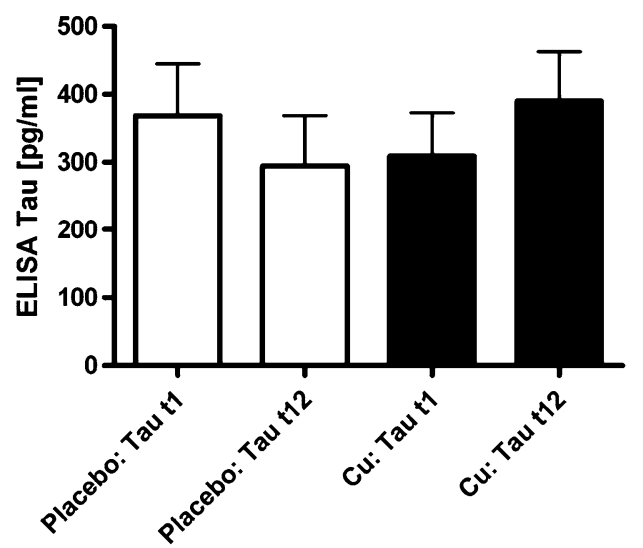

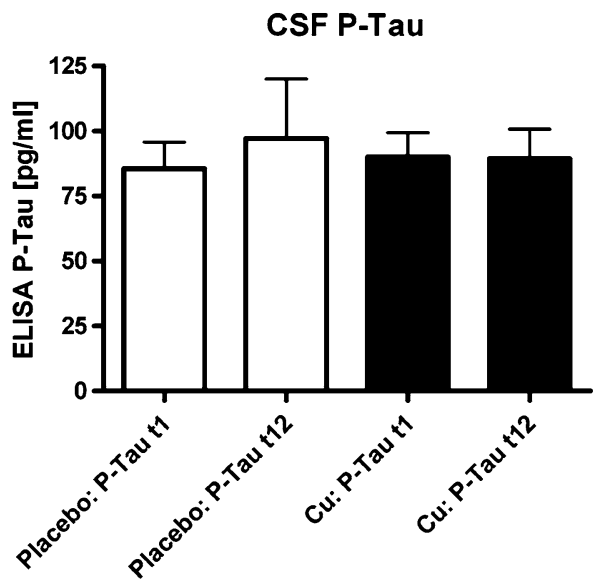

normal distributed therefore MANOVA analysis with repeated measures design was used. Again, P-Tau levels showed no significant differences (Fig. 1). There were no significant correlations for the change over time $\left(t_{12}-t_{1}\right)$ between $\mathrm{Cu}$ values in CSF and cholesterol (placebo: $\rho=$ $0.33 ; d f=12 ; P=0.25$, verum: $\rho=-0.15 ; d f=10$; $P=0.64)$ as well as between CSF-Cu and CSF-A $\beta 42$ (placebo: $\rho=0.32 ; d f=10 ; P=0.31$, verum: $\rho=-0.39$; $d f=12 ; P=0.16)$.

\section{Discussion}

APP and $\mathrm{A} \beta$ are both metalloproteins which bind $\mathrm{Cu}$ in vitro and were suggested to be involved in brain $\mathrm{Cu}$ homeostasis. Maynard et al. (2002) have shown that overexpression of the $\mathrm{A} \beta$ sequence contained within a carboxy-terminal fragment of APP elicits significantly reduced $\mathrm{Cu}$ levels in transgenic mouse brain. This effect might be further enhanced by the drastically reduced bioavailability of $\mathrm{Cu}$ possibly due to the binding to plaque $\mathrm{A} \beta$ (Lovell et al. 1998).
The APP mediated $\mathrm{Cu}$ efflux activity observed in APP overexpressing living cells best explained the intracellular $\mathrm{Cu}$ deficiency and a subsequently reduced SOD-1 activity (Bayer et al. 2003; Treiber et al. 2004). In addition, a genetically 1.5-fold up-regulated $\mathrm{Cu}$ level was associated with an increased survival of APP transgenic mice and lowered endogenous murine $\mathrm{A} \beta$ levels prior to detectable A $\beta$ plaques formed by the human APP transgene (Phinney et al. 2003). These observations led us conclude that restoring brain $\mathrm{Cu}$ homeostasis might have a beneficial influence on the progression of $\mathrm{AD}$ biomarkers. Thus, in the present clinical trial we investigated potential beneficial effects of oral intake of $\mathrm{Cu}$-(II)-orotate-dihydrate $(8 \mathrm{mg} \mathrm{Cu}$ daily) in $\mathrm{AD}$ patients and CSF was collected at beginning and at the end of the study after 12 months.

The treatment was generally well tolerated although there was no clear-cut beneficial effect on CSF biomarker levels in $\mathrm{AD}$ patients. One may speculate that $\mathrm{Cu}$ treatment normalized $\mathrm{Cu}$ levels in plasma in the verum group by enhanced uptake and transport and improved tissue homeostasis. The plasma $\mathrm{Cu}$ levels declined only in the placebo group during the 12-months period, however the 
placebo group had higher $\mathrm{Cu}$ levels at the beginning of the study by accident. $\mathrm{Cu}$ levels in the verum group were unchanged, which seems to be paradoxical. Previously, we have reported that significantly lower levels of $\mathrm{Cu}$ in plasma were found in those $\mathrm{AD}$ patients, who fulfilled the criteria of CSF diagnosis for AD (Kessler et al. 2006). In addition we demonstrated reduced $\mathrm{Cu}$ levels in plasma in patients with higher ADAScog scores (making more mistakes in this neuropsychological test) (Pajonk et al. 2005).

Reduced CSF levels of the $\mathrm{A} \beta 42$ in $\mathrm{AD}$ patients have been found in numerous studies, with high sensitivity and are commonly used for diagnostic evaluation [reviewed in (Andreasen et al. 2003)]. We also observed that $\mathrm{A} \beta 42$ levels were reduced using Western blot and ELISA techniques after a 12 month observation period corroborating these earlier studies. However we did not find a change in Tau or Phospho-Tau levels over time. On the other side FDG-PET, PIB-PET and fMRI may be more suitable as in vivo pathological markers.

Recently, it has been demonstrated that CSF $\mathrm{Cu}$ levels negatively correlate with $\mathrm{A} \beta 42$ levels in $\mathrm{AD}$ patients (elevated $\mathrm{Cu}$ and decreased $\mathrm{A} \beta 42$ ) (Strozyk et al. 2007). In good agreement with this report, we found that $\mathrm{Cu}$ treatment apparently had a small effect on $\mathrm{A} \beta 42$ levels. A $\beta 42$ declined in both the verum and placebo groups over time however much more dramatically with $30 \%$ in the placebo group $(P=0.001)$. The A $\beta 42$ levels declined only by $10 \%$ in the verum group $(P=0.04)$. In contrast to this observation $\mathrm{Cu}$ treatment had no beneficial effect on cognitive abilities tested by MMSE and ADAS-cog in AD patients of the present clinical phase II pilot study as already shown (Kessler et al. 2008). No effect on cognitive performance and a stabilizing effect on CSF A $\beta 42$ levels is to be contradictory and therefore needs further and independent evaluations.

One animal study showed that treatment of 21-monthsold Tg2576 mice with clioquinol, a $\mathrm{Cu}, \mathrm{Zn}$ chelator, inhibited plaque formation and concomitantly increased soluble brain $\mathrm{Cu}$ and $\mathrm{Zn}$ levels (Cherny et al. 2001). Moreover, lowered insoluble $\mathrm{A} \beta$ levels (by 49\%) and increased soluble $\mathrm{A} \beta$ levels (by 50\%) were accompanied with elevated $\mathrm{Cu}$ levels (and $\mathrm{Zn}$ ). This increase of $\mathrm{Cu}$ - and $\mathrm{Zn}$-ions might either be attributed to an inefficiency of the chelator with its known weak affinities for $\mathrm{Zn}\left(K_{1}=7.0\right)$ and for $\mathrm{Cu}\left(K_{1}=8.9\right)$ or even more likely, due to a facilitated uptake in brain of clioquinol- $\mathrm{Cu}$ complexes. The latter hypothesis has been experimentally confirmed in a yeast system in vitro (Treiber et al. 2004).

When $\mathrm{AD}$ patients were treated with clioquinol, the placebo group deteriorated faster than the clioquinol group suggesting a beneficial effect upon clioquinol treatment (Ritchie et al. 2003). In contrast, clioquinol treatment of APP transgenic mice was associated with premature death, which could be rescued by $\mathrm{Cu}$ supplementation (Schäfer et al. 2007). At present there is no simple explanation for these apparently contradictory results.

Sparks and Schreurs (2003) challenged rabbits with a high-cholesterol diet and reported that the intake of minor concentrations of $\mathrm{Cu}(0.12 \mathrm{mg} / \mathrm{l})$ in the drinking water impaired behavior and induced plaque-like structures in the hippocampus and temporal lobe. These surprising findings implied that tap water $\mathrm{Cu}$ concentration might influence AD. In the present study we did not find any correlation between plasma or CSF $\mathrm{Cu}$ and cholesterol levels.

Postmortem $\mathrm{Cu}$ levels in CNS of AD patients were found decreased (Deibel et al. 1996) or unchanged (Loeffler et al. 1996). Controversial results have also been published on the level of $\mathrm{Cu}$ in plasma and brain in $\mathrm{AD}$ patients. Plasma $\mathrm{Cu}$ levels being within the normal range $(65-165 \mu \mathrm{g} / \mathrm{dl})$ in AD patients are in good agreement with an earlier study (Jeandel et al. 1989). However, other studies suggest that elevated $\mathrm{Cu}$ levels might be a risk factor for $\mathrm{AD}$ without providing a rationale (Squitti et al. 2002, 2003, 2004). These results are in contrast to the present study, which might be explained by the fact that we studied $\mathrm{Cu}$ levels in the same patients within a 12 months period and can therefore better control for inter-individual differences. Short-term high $\mathrm{Cu}$ intake has been reported not to affect $\mathrm{Cu}$ status or functions related to $\mathrm{Cu}$ status, only long-term high $\mathrm{Cu}$ intake can result in increases in some parameters in young men (Turnlund et al. 2004).

The present clinical trial demonstrates that long-term oral intake of $8 \mathrm{mg} \mathrm{Cu}$ [Cu-(II)-orotate-dihydrate] can be excluded as a risk factor for AD based on CSF biomarker analysis. In addition, $\mathrm{A} \beta 42$ levels declined significantly within 12 months in CSF indicating its value as a prognostic biomarker in addition to its common use for diagnosing AD.

Acknowledgments The excellent technical help of Patricia Nagel, Katrin Rubly, Karl-Heinz Hoffmann, and Irene Witzmann is gratefully acknowledged. Financial support was provided by the HOMFOR program of the Saarland University Medical Faculty and the International Copper Association. This work has been supported in part by the International Copper Association (to T.A.B.) and Saarland University (HOMFOR program to F.-G. P.). The authors report no conflicts of interest. We have full control of the primary data and agree to allow the journal to review the data if requested.

Open Access This article is distributed under the terms of the Creative Commons Attribution Noncommercial License which permits any noncommercial use, distribution, and reproduction in any medium, provided the original author(s) and source are credited.

\section{References}

Andreasen N, Sjogren M, Blennow K (2003) CSF markers for Alzheimer's disease: total tau, phospho-tau and Abeta42. World J Biol Psychiatry 4(4):147-155

Atwood CS, Scarpa RC, Huang X, Moir RD et al (2000) Characterization of copper interactions with Alzheimer amyloid beta 
peptides: identification of an attomolar-affinity copper binding site on amyloid beta1-42. J Neurochem 75(3):1219-1233

Barnham KJ, McKinstry WJ, Multhaup G, Galatis D et al (2003) Structure of the Alzheimer's disease amyloid precursor protein copper binding domain. A regulator of neuronal copper homeostasis. J Biol Chem 278(19):17401-17407

Bayer TA, Wirths O, Majtenyi K, Hartmann T et al (2001) Key factors in Alzheimer's disease: beta-amyloid precursor protein processing, metabolism and intraneuronal transport. Brain Pathol 11(1): $1-11$

Bayer TA, Schäfer S, Simons A, Kemmling A et al (2003) Dietary Cu stabilizes brain SOD-1 activity and reduces amyoid AB production in APP23 transgenic mice. Proc Natl Acad Sci USA 100(24):14187-14192

Borchardt T, Camakaris J, Cappai R, Masters CL et al (1999) Copper inhibits beta-amyloid production and stimulates the non-amyloidogenic pathway of amyloid-precursor-protein secretion. Biochem J 344(Pt 2):461-467

Bush AI (2003) The metallobiology of Alzheimer's disease. Trends Neurosci 26(4):207-214

Cherny RA, Atwood CS, Xilinas ME, Gray DN et al (2001) Treatment with a copper-zinc chelator markedly and rapidly inhibits beta-amyloid accumulation in Alzheimer's disease transgenic mice. Neuron 30(3):665-676

Deibel MA, Ehmann WD, Markesbery WR (1996) Copper, iron, and zinc imbalances in severely degenerated brain regions in Alzheimer's disease: possible relation to oxidative stress. J Neurol Sci 143(1-2):137-142

Glenner GG, Wong CW (1984) Alzheimer's disease: initial report of the purification and characterization of a novel cerebrovascular amyloid protein. Biochem Biophys Res Commun 120:885-890

Hesse L, Beher D, Masters CL, Multhaup G (1994) The beta A4 amyloid precursor protein binding to copper. Febs Lett 349(1): 109-116

Jeandel C, Nicolas MB, Dubois F, Nabet-Belleville F et al (1989) Lipid peroxidation and free radical scavengers in Alzheimer's disease. Gerontology 35(5-6):275-282

Kang J, Lemaire HG, Unterbeck A, Salbaum JM et al (1987) The precursor of Alzheimer's disease amyloid A4 protein resembles a cell-surface receptor. Nature 325:733-736

Kessler H, Pajonk FG, Supprian T, Falkai P et al (2005) [The role of copper in the pathophysiology of Alzheimer's disease.]. Nervenarzt 76(5):581-585

Kessler H, Pajonk FG, Meisser P, Schneider-Axmann T et al (2006) Cerebrospinal fluid diagnostic markers correlate with lower plasma copper and ceruloplasmin in patients with Alzheimer's disease. J Neural Transm 113(11):1763-1769

Kessler H, Bayer TA, Bach D, Schneider-Axmann T et al (2008) Intake of copper has no effect on cognition in patients with mild Alzheimer's disease - a pilot phase 2 clinical trial. J Neural Transm 115(8):1181-1187

Lewczuk P, Esselmann H, Otto M, Maler JM et al (2004) Neurochemical diagnosis of Alzheimer's dementia by CSF Abeta42, Abeta42/Abeta40 ratio and total tau. Neurobiol Aging 25(3):273-281

Loeffler DA, LeWitt PA, Juneau PL, Sima AA et al (1996) Increased regional brain concentrations of ceruloplasmin in neurodegenerative disorders. Brain Res 738(2):265-274

Lovell MA, Robertson JD, Teesdale WJ, Campbell JL et al (1998) Copper, iron and zinc in Alzheimer's disease senile plaques. J Neurol Sci 158(1):47-52

Maynard CJ, Cappai R, Volitakis I, Cherny RA et al (2002) Overexpression of Alzheimer's disease amyloid-beta opposes the age-dependent elevations of brain copper and iron. J Biol Chem 277(47):44670-44676

McKhann G, Drachman D, Folstein M, Katzman R et al (1984) Clinical diagnosis of Alzheimer's disease: report of the NINCDS-ADRDA Work Group under the auspices of Department of Health and Human Services Task Force on Alzheimer's Disease. Neurology 34(7):939-944

Multhaup G, Schlicksupp A, Hesse L, Beher D et al (1996) The amyloid precursor protein of Alzheimer's disease in the reduction of copper(II) to copper(I). Science 271(5254):1406-1409

Pajonk F, Kessler H, Supprian T, Hamzei P et al (2005) Cognitive decline correlates with low plasma concentrations of copper in patients with mild to moderate Alzheimer's disease. J Alzheimers Dis 8(1):23-27

Phinney AL, Drisaldi B, Lugowski S, Schmidt S et al (2003) In vivo reduction of amyloid $A B$ by a mutant copper transporter. Proc Natl Acad Sci USA 100(24):14193-14198

Ritchie CW, Bush AI, Mackinnon A, Macfarlane S et al (2003) Metal-protein attenuation with iodochlorhydroxyquin (clioquinol) targeting Abeta amyloid deposition and toxicity in Alzheimer disease: a pilot phase 2 clinical trial. Arch Neurol 60(12):1685-1691

Schäfer S, Pajonk FG, Multhaup G, Bayer TA (2007) Copper and clioquinol treatment in young APP transgenic and wild-type mice: effects on life expectancy, body weight, and metal-ion levels. J Mol Med 85(4):405-413

Sparks DL, Schreurs BG (2003) Trace amounts of copper in water induce beta-amyloid plaques and learning deficits in a rabbit model of Alzheimer's disease. Proc Natl Acad Sci USA 100(19):11065-11069

Squitti R, Lupoi D, Pasqualetti P, Dal Forno G et al (2002) Elevation of serum copper levels in Alzheimer's disease. Neurology 59(8):1153-1161

Squitti R, Pasqualetti P, Cassetta E, Dal Forno G et al (2003) Elevation of serum copper levels discriminates Alzheimer's disease from vascular dementia. Neurology 60(12):2013-2014

Squitti R, Cassetta E, Dal Forno G, Lupoi D et al (2004) Copper perturbation in 2 monozygotic twins discordant for degree of cognitive impairment. Arch Neurol 61(5):738-743

Strozyk D, Launer LJ, Adlard PA, Cherny RA et al (2007) Zinc and copper modulate Alzheimer Abeta levels in human cerebrospinal fluid. Neurobiol Aging 10.1016/j.neurobiolaging.2007.10.012

Treiber C, Simons A, Strauss M, Hafner M et al (2004) Clioquinol mediates copper uptake and counteracts copper efflux activities of the amyloid precursor protein of Alzheimer's disease. J Biol Chem 279(50):51958-51964

Turnlund JR, Jacob RA, Keen CL, Strain JJ et al (2004) Long-term high copper intake: effects on indexes of copper status, antioxidant status, and immune function in young men. Am J Clin Nutr 79(6): 1037-1044

White AR, Reyes R, Mercer JF, Camakaris J et al (1999) Copper levels are increased in the cerebral cortex and liver of APP and APLP2 knockout mice. Brain Res 842(2):439-444

Wiltfang J, Esselmann H, Maler JM, Bleich S et al (2001) Molecular biology of Alzheimer's dementia and its clinical relevance to early diagnosis and new therapeutic strategies. Gerontology 47(2):65-71

Wiltfang J, Esselmann H, Bibl M, Smirnov A et al (2002) Highly conserved and disease-specific patterns of carboxyterminally truncated Abeta peptides $1-37 / 38 / 39$ in addition to $1-40 / 42$ in Alzheimer's disease and in patients with chronic neuroinflammation. J Neurochem 81(3):481-496 